\title{
A NEED OF ENVIRONMENTAL LEGAL FRAMEWORK EVOLUTION
}

Sydor V. D.

\section{INTRODUCTION}

The importance of research on overcoming the gaps and solving conflicts in environmental legislation on the state lawmaking processes, identify their watershed character, qualitatively new state of society and the new challenges faced by national environmental legislation and law. Nowadays the environmental laws and legislation cannot avoid gaps in the legal regulation of environmental relations.

Gaps in environmental law and legislation affecting the implementation of subjective rights to natural objects, the performance of legal duties to protect the natural objects, but also make it difficult or even impossible to protect rights and interests in the emergence of new environmental relations. Lack of legal regulations only required amount of environmental relations is an objective factor that predetermined lag environmental legislation of Ukraine from changing environmental relations. Therefore, the presence of gaps in the environmental legislation requires solving the problem of their elimination. Gaps in environmental law should be considered in the absence of a specific provision legal act.

Gaps in environmental law and legislation affecting the efficiency of the legal regulation of environmental relations. Gaps, which is one of the legal defects of the environmental law, will have a significant negative impact on the regulation of environmental relations. To detect the presence of gaps environmental regulation to establish that certain environmental relations within the scope of legal regulation. In addition to detecting the absence or incompleteness of the legal regulation of environmental relations, to prove the need for their legal support.

\section{Directions for Improving Environmental Legislation by Eliminating Gaps and Collisions}

Gaps in environmental law is undesirable as it causes many negative consequences, preventing a stable full protection of rights. Imprecision in the language, incorrect or incomplete use of tools and techniques of legal technology, gaps in the regulation of individual relationships - it causes difficulty in the implementation of legal norms ${ }^{1}$.

\footnotetext{
${ }^{1}$ Алексеев С. С. Общая теория права: в 2-х т. М. : Юрид. лит., 1981. Т. 1. С. 93.
} 
Gaps in current environmental law and legislation is a negative phenomenon that destabilizes public environmental relations. The destructive potential of gaps in environmental legislation is particularly dangerous during the land reform and radical transformation of legal institutions. In modern terms of legislation, a lot of the problems of subjective and objective nature caused by such violations during legislative work:

(a) the discrepancy of certain provisions of a number of regulations of the fundamental principles of the Constitution of Ukraine, the practice of making changes to existing laws, sub-legal acts, which complicates the process of law;

(b) parallel existence of regulations that are issued at different times by different government agencies and content contradict each other, lack the necessary consistency and the relationship between regulations, which complicates the process of their implementation;

(c) imperfection content of new regulations, unfounded and inappropriate use of complex terminology, borrowing foreign language that makes legal act incomprehensible and inaccessible to perception.

Gaps is a lack of environmental law system of legal regulations regarding the circumstances that lie in the field of regulation and require legal impact. The gaps in the legal regulation of environmental relations - a state of legal uncertainty arising from the total or partial absence of objectively necessary link in the legal impact of environmental relations. The presence of gaps in the environmental law and legislation is an objective phenomenon, which can not be avoided even by the most perfect and detailed legal regulation.

The reasons for the gaps in environmental law are:

- the inability legislator to represent normative prescriptions in the variety of life situations that require legal regulation (primary gap);

- legislator inability to predict the emergence of new situations as a result of continuous development of social relations, to carry them on some legislative acts (secondary gap);

- technical errors legislator made in the development of laws and methods of use of legal technology.

Gaps in environmental law - is a situation of legal irregularity existing environmental relations that require legal regulation and protection, and the environmental laws completely or partially missing the required legal standard.

Types of gaps:

1) full gap - in environmental legislation necessary for regulating environmental relations norms;

2) partial gap - the presence of the required rate, but it could not use.

The presence of gaps in the environmental legislation is a factor that reduces the effectiveness of the legislation in the field of regulation of 
environmental relations. The presence of gaps can be combined with the efficiency of the functioning of the legal regulation of environmental relations if the current legislation provides effective means to overcome gaps in the law enforcement activities. Gaps in environmental law is a negative phenomenon that destabilizes environmental relations.

Flaws and contradictory environmental laws adversely affecting the work of all branches of government, greatly complicates the tasks facing them significantly reduces the ability of legislation to effectively regulate social relationships weaken the regime legitimacy affects not the level of law and order in the country hinders the implementation of human rights and freedoms and citizen. Installing the gaps in the legal regulation of environmental relations and their management are two components of a single thought process based on the same logical operations, which in turn are related to the ways interpretation of environmental laws. Filling gaps means filling passage in the law, overcoming the gaps is meant to shift through the gap without filling its content.

Therefore, the role means to fill the gaps, can play only a source of law. Bridging gaps in law by applying the law for Ukraine is not traditional, so the gaps are eliminated through the issuance of new legal act or amending the previous Act, or cancels. Incomplete regulation of environmental relations opens the way for the creative capabilities of law enforcement in the selection of its activities.

However, the legal uncertainty in resolving environmental issues to deal with than their discretion so that obtained from the decision was fair, did not violate the rule of law. Environmental legislation in general is characterized by lack of integrity for the effective regulation of environmental relations, the presence of internal contradictions, gaps and ambiguous provisions, lack of standards that promote the development of market mechanisms for environmental use and protection, availability of interbranch conflict, lack of an integrated approach to the legal regulation of environmental relations. Environmental laws based on outdated approaches may even promote the deepening crisis in environmental relations.

Mechanism to overcome gaps in environmental law is a set of interrelated and interacting regulatory and organizational institutions by which defined areas of filling and close the gaps in the environmental law, the increase of the efficiency of the legal regulation of environmental relations.

Bridging gaps in environmental legislation involves removing gaps in the legal regulation of environmental relations through the activities of the Verkhovna Rada of Ukraine aimed at the ultimate elimination of legal irregularity environmental relations, normative and casual filling in gaps in environmental law. Normative fill gaps by using interpretation of authorities 
having jurisdiction in the interpretation of delegated legislation. Casual filling gaps implemented by officials of state and local authorities in the field of natural objects use and protection in the implementation of specific law enforcement activities.

Gaps in current environmental legislation is one of the causes of the crisis of law in environmental relations. Complex problem of collisions of environmental legislation. Stability regulation of environmental relations largely depends on the quality of the system of environmental laws and rights, which is currently unbalanced and has internal contradictions.

One of the main reasons for the low efficiency of the regulatory capacity of environmental law is the existence of collisions. Contradictions of the key issues of legal regulation of environmental relations in Ukraine reduce the effectiveness of the mechanism of regulation. Requires a clear mechanism to prevent and resolve to overcome and eliminate the phenomenon of collisions that prevents the development of environmental laws.

The rapid development of environmental legislation creates controversy related to the difference in the time the legislation passed, and the fact that some laws are not consistent with each other.

Collisions in environmental law and legislation in the broadest sense - is legal controversies that can go into open legal conflicts, and expressed not only in legal norms, but also in the interests of the opposing environmental relationships. Collisions in environmental law and legislation in the narrow sense - a contradiction between individual environmental legal provisions aimed at regulating the same environmental relations.

Competing in the legal regulation of environmental relations - a difference or discrepancy, the discrepancy between the requirements of regulations governing the same social relations associated with the use, protection and restoration of natural objects and can not be used simultaneously.

Collisions of environmental law is objective phenomenon. It is the content differences between two or more legal acts adopted with one and the same issue. Conflicts prevent proper application of the law and thus reduce its effectiveness. Reasons of collisions related to the quality of environmental laws and rights of insufficient systemic nature of their development. Therefore, the development of environmental laws and legislation is impossible without improving the efficiency of the legal impact of environmental relations.

Collisions in environmental legislation determined by the objective and subjective factors of social development. This formal contradiction between the rules of law aimed at regulating the same relations in the rational and purposeful use, integrated playback and effective protection of natural objects, creating difficulties in enforcement activity. 
The main factors that cause collisions in environmental legislation are objective factors (statics of environmental law and dynamics of environmental relations) and subjective factors (lack Concept of environmental law, poor training legislator, violations of legal technique, inconsistent legislative activity in the legal regulation of environmental relations, improper ordering of environmental law).

Collisions in environmental law is a conflict or discrepancy between the requirements of regulations governing the same legal relationship, and are in the process of their application by the competent authorities; collisions is the kind of contradiction in the legislation of Ukraine, resulting from the manifestation of various complex, objective and subjective reasons, economic, political, social, legal.

In the area of regulation arise collisions of two kinds: material - between public environmental relations; formal - between legal regulations. Legal collisions - is due to objective and subjective factors of social development formal contradiction (the difference) between the rule of law (complex legal rules), between the rule of law and interpretation of acts aimed at regulating the same social relations that creates difficulties in law enforcement ${ }^{2}$.

Typical shortcomings environmental law is a contradiction between the newly admitted and current regulations, by the laws and regulations. Sometimes there is a discrepancy regulations of the same legal act, distortions in them fundamental, basic principles and the principles of environmental law. Contradictory, duplication, gaps in the legal regulation of environmental relations and the lack of effective mechanisms for the implementation of the environmental law have become commonplace in lawmaking practice.

All this creates problems with performance acts environmental laws, complicating law enforcement practices. Modern environmental law does not fully satisfy the growing needs of the implementation of constitutional rights and freedoms of man and citizen, the effective implementation of the tasks and functions of the democratic, social, rule of law, does not meet the level of maturity of civil society and perspectives of its development. In order to improve the current situation and improve the efficiency of environmental legislation, the main effort in our opinion, lawmakers should focus on the development of the concept of environmental legislation of Ukraine.

Legal doctrine has created a theoretical framework for the prevention, elimination and resolution of legal collisions. The main ways of preventing collisions is fixing in law collision rules, the abolition of (changes) of one or

2 Майстренко О. В. Теоретико-правові аспекти колізій у законодавстві України: автореф. дис. на здобуття наук. ступеня канд. юрид. наук: спец. 12.00.01; Нац. ун-т внутр. справ. Х., 2008. С. 9. 
all of the collision rules are in conflict. One of the main ways of dealing with collisions is systematization of environmental legislation. Negative collisions of environmental legislation giving rise to the alternative choice of the most convenient norm in the process of solving a particular case, thus creating a real option of ignoring the rule of law and legality in the implementation of the law, distort the legal culture and generate legal nihilism. Collisions offer opportunities for the manifestation of subjectivity persons in the application of legal norms.

The basic rules resolve collisions in the legal regulation of relations are:

1) the principle of resolving collisions law by legal force of acts;

2) the principle of resolving collisions by legal rule "later act";

3) the principle of resolving collisions law by the rule of "special rules"3.

Legal validity of a legal act affects a meaningful reflection of its impact on social relations to overcome the significant shortcomings of current legislation, identifying and finding ways to resolve the conflicts between the old and new rules regulations. To overcome the collision of environmental legislation can be achieved by streamlining the system of environmental law and maintain its equilibrium by setting strict grading regulations and its compliance in the rulemaking.

Collisions can be resolved by maintaining the legal system in the state of functional equilibrium. It is important to eliminate the double regulation of environmental relations. It is unacceptable placing similar regulations in various fields of law - a direct and inevitable consequence of this is the collision. Eliminating duplication and preventing it should be guided by the principle: the regulation of environmental relations should be as general as possible. With proper construction of the legislation (as in "special" legislation will be placed really special orders, and "general" - general) needs a "collision rules" that specify the relationships between the different branches of legislations, will not - instead them will apply the general principle of conflict "special rule". If the legislation is built correctly, and "general" law contains special rules "collision rule" only harm.

The main preventive measures against collisions in environmental law and legislation:

- forecasting and planning of legislative activity, improve technique of legislation, legal examination regulations;

- systematization of legislation.

Mechanism of overcome environmental laws collisions is a set of legal tools, techniques and procedures aimed at preventing new address and

\footnotetext{
${ }^{3}$ Мірошниченко А. М. Колізії в правовому регулюванні земельних відносин в Україні: монографія.; Ін-т законодавства Верховної Ради України. К.: Правова єдність, 2009. С. 62.
} 
overcome existing conflicts in environmental law. The structure of the mechanism to overcome environmental laws collisions includes the following components: a rule-making, collision rules and systematization of environmental legislation.

The dynamics of environmental legislation of Ukraine is characterized by extremely complex and contradictory processes. As a result of active legislative activities significantly increased the number and at the same time contradictory legal regulations. Environmental legislation has large amount, a lot of collisions, often legal rules governing the same environmental relations are duplicated in different regulations. Quality environmental law is defined as a set of essential features of the law that reflect its merits and determine the ability and opportunity to environmental legislation to meet the needs and interests of society and citizens in natural objects use and protection. Environmental legislation has many parameters, while in different environmental relations appear specific to each case as environmental laws, which vary with the development of environmental relations.

Quality parameters of environmental legislation can be divided into three groups:

1) features that reflect the essence of environmental law as a legal phenomenon (rule, normativity, formality);

2) features that reflect the degree of perfection of environmental law (his correspondence to the real environmental issues, resource support, compliance with the Constitution);

3) features that reflect the results of the environmental laws (reality, stability, dynamics).

The tension between legal prescriptions today permeate the entire system of environmental laws. In its structure now clearly seen some negative trends - needless multiplicity of acts in the regulation of environmental relations alone while their failure in the regulation of other environmental relations, the imbalance of the legislative process, numerous violations of procedures for the adoption of laws and rules of legislative technique ${ }^{4}$.

Improving environmental laws - is the work of the competent authorities of the state to maintain the quality of legislation (the quality of its content and form) according to the needs of environmental relations, which aims to ensure effective regulation.

Based on these criteria to form the improvement of environmental law and legislation include:

4 Сидор В. Д. Земельне законодавство України: сучасний стан та перспективи розвитку: монографія. К.: Вид-во “Юридична думка", 2011. С. 138. 
- discussion of draft regulations, approval of draft legal acts, examination of bills signed by the President,

- state registration regulations relevant legal authorities amendment and revision of existing regulations,

- elimination of illegal applicable regulations,

- the official regulatory interpretation of existing regulations, termination is unconstitutional and illegal regulations judicial decisions ordering regulations.

Enhancing the role of the legal regulation of environmental relations requires streamlining of legislation that provides for simultaneous updates of laws through the adoption of new and improvement of existing regulations.

The specific shortcomings environmental legislation include:

- uncertainty priorities in making laws, instability and internal contradictions of laws and their individual rules;

-imbalance in the ratio of the laws, regulations and administrative regulations,

- lack of scientific validity of the legislation, and their declarative addressless others.

Given the large number of regulations environmental laws, high level of collisions of prescriptions, gaps and other defects environmental regulation, the need for its systematic long overdue.

Conducting systematic aimed at finding and solving conflicts, identify ineffective rules and replace them with more efficient legal requirements, clearing accumulated legal material by eliminating duplication of regulation and ineffective regulations, identify gaps in the legal regulation of environmental relations and their filling, ordering rules of environmental law and enforcement them in a system to improve the efficiency of the legal regulation of environmental relations in Ukraine.

To ensure consistency of the existing array of environmental legislation of Ukraine in the legislative work to be solving interrelated objectives:

- improvind the existing environmental laws,

- the elimination of gaps in the legal regulation of environmental relations,

- overcoming collisions of environmental legislation,

- develop recommendations for further areas of environmental legislation providing for solving problems of lawmaking.

The most common shortcomings environmental legislation are:

- inconsistency environmental issues, interests and needs of people;

- the contradiction between legal norms;

- low level of systematization;

- lack of sharpness and clarity of the legal requirements and regulations, which leads to a violation of law in the field of environment. 


\section{The Ratio of Public and Private Components in Environmental Legislation}

Science of environmental law is going through a difficult period, associated with changes in the principle value of public and private interest in the regulation of environmental relations. In present conditions of Ukraine's legal system sharpened debate on the division of law to the appropriate field, distinguishing public law and private-law institutions. One of the effective steps of improvement of legislation is the optimization of private and public law principles in establishing the mechanism of regulation. The Constitution of Ukraine created the necessary conditions for the formation and establishment of a new environmental law considering the transition to a market economy and secures new conceptual basis for regulating environmental relations.

Public law type of regulation is characterized by the fact that in the areas of public law in the first place are obligations of participants of public relations in its various forms (prohibitions, regulations, etc.). By the nature of norms and orientation influence public law is mainly imperative, and the main result of his influence should be strict implementation of the participants of public relations requirements contained in the law.

Public legal principles of environmental legislation of Ukraine is objectively due to the principles that determine the need, purpose, features, content and the use of public law in the mechanism of regulation ${ }^{5}$. The object of public legal restrictions may be any fixed in-law environmental rights. The ways of the law on public legal restrictions of environmental rights is a normative set of boundaries and limitations purposes, restraining orders, list of facilities and the range of subjects related environmental rights.

Lack of necessary scientific basis transformation property in Ukraine, imperfections and dynamics of the law in this area is not conducive to effective legal regulation of environmental relations. In today's special urgency and severity is the question of public law principles of environmental law, public ownership, its subjects and objects. From the solution of this question depends largely on the integrity of the state, effective protection and use of natural resources, the interests of the population of Ukraine and local communities. The intervention of public law principles in the sphere of property aimed at protecting the interests of the whole society.

That feature of the environmental law is that it is a sphere interaction of private and public interests, and therefore the regulation of environmental

5 Костицький В. Міжнародно-правовий етичний імператив як основа теоретикометодологічного забезпечення розвитку екологічного права. Право Украӥни. 2011. № 2. C. 30 . 
relations is done using public law and private law means. Urgent task in conducting legal policy is to ensure optimal ratio of public law and private law principles in the environmental law in establishing a stable order in the country.

Soviet jurisprudence did not recognize the separation of the right to private and public. The main motive of the denial of the division was that the basis of private law, private property, and if it is missing, the missing, and private law. Today recognition of private ownership on natural resources causes the development of private foundations in environmental law.

Private regulation of environmental relations is characterized by the following principles as the recognition and protection of private ownership, independence and autonomy of the subjects of environmental relations, equality of subjects ownership. It is in these aspects of private regulation of environmental relations intervene public legal means, resulting in a restriction of the right of private ownership, a restriction on freedom of transactions. Penetration of private regulation in environmental relations includes not only the creation of new institutions, but also rethinking those who are traditional environmental rights. Statewide legislation is an independent branch of the law of Ukraine is a system of regulations that govern environmental relations. The foundation of the formation of modern environmental law were laid in the last decade of the last century.

Modern environmental law considers the natural objects together: as a natural resource and as property. Environmental legislation, combining private legal and public legal methods of influence, designed and capable of ensuring the rational use and protection of natural resources.

There is a need to improve the mechanism of incorporation of public interest in private law rules governing environmental relations, and the problem is also the so-called inverse penetration of public law principles in modern private law. The interpenetration of public law and private law principles creates the need to develop the modern theory of environmental law in the direction of seeking their optimal value and interaction.

Environmental legislation in its substantive sense is a set of rules aimed at protecting public and private environmental interests. Environmental interests considered constructing category as a decisive factor in the impact and meaning of the environmental law, the driving force of their motive and behavior of environmental relations. External criteria publicity environmental interests is standard form of expression. It is important to study the problem of establishing balance, finding a universal correlation between the public and of private interests. There is a need to unite in a fundamentally new scientific issue series of general and sectoral aspects of security and protection of environmental rights. 
This is due, on the one hand, dynamic environmental conditions of formation and use of environmental legislation, sharpening needs of economic development and environmental interests of society, increased exploitation of natural resources in current market conditions, on the other hand - the practical needs in the legislative process and enforcement activity theoretical concepts justifying the ways of legal harmonization of various environmental interests. Criteria rights division between public and private but well-known criteria subject and method of regulation may serve interest. Interest is the values, target and meaningful basis impetus to normative mediation and development of any subjective rights. Value of public law and private law interests in the legal regulation of environmental relations are legally legal indicator of the quality of the political regime in the relevant historical and legal point of society.

A special way to regulate the relations of public interests in environmental law formed mainly of prohibitions and regulations, public-legal restrictions on economic activities, subject composition owners and users, functional and regional use restrictions. Legal restrictions can be seen in the narrow and broad sense: as either a synthetic method of legal regulation, which is formed mainly prohibitions and obligations as a generic term that includes the proper restrictions, encumbrances and different requirements imposed on the subjects of environmental relationships. Existing in environmental law set limits is an important tool for regulating environmental relations. Purpose of legal restrictions is to ensure public environmental interests.

The source of public legal restrictions is a constitutional provision. Since the constitutional provisions of Art. 13 on the property of the Ukrainian people to all natural resources within the territory of Ukraine follows the principle of equal access to natural objects. Equality and fairness in environmental relations based on formal, legal equality. The principle of legal equality involves the introduction state the conditions under which any entity of environmental rights may be subject of environmental relations. Restriction of economic activities in order to ensure public environmental interests should be imposed by the current environmental legislation under the Constitution of Ukraine, based on guaranteed constitutional right of every citizen. The constitutional and legal position justification environmental legal restrictions possible on the basis of second part of Article 13 of the Constitution of Ukraine, which secures that the property should not be used to the detriment of the person and society ${ }^{6}$. An important task is to determine the extent of lawmaking admissibility limit private interests to protect the environmental rights of citizens and public environmental interests.

${ }^{6}$ Конституція України, прийнята на п'ятій сесії Верховної Ради України 28 червня 1996 року. URL: https://zakon.rada.gov.ua/laws/show/ 
An important way to ensure the public interest is the regulation of free access of all citizens to the natural resources to ensure freedom of movement and enjoyment of aesthetic, recreational, recreational needs.

Unity and cooperation of public law and private law principles based on the use of general categories and concepts developed in the theory of law, such as the rule of law, prohibitions, permissions, responsibilities, etc. Private and public law serve as two main areas of regulation, each of which governs the appropriate field of public relations.

The object of science is the study of environmental law legal regulation of environmental relations, including the problem of interaction between public law and private law principles of their regulation. Studies of various legal phenomena only from the standpoint of public or private law do not give full and comprehensive understanding of their legal nature, do not allow to achieve the goal of complex study of complex processes and phenomena suggest effective ways of improving environmental legislation.

Private and public law in all developed legal orders continue to exist as two separate, independent branches regulation as two different types of legal impact on social relations. However, it should recognize and take into account that the private and public sector is always communicate with each other, resulting in some emerging areas of law in which the elements of public law regulation penetrate the private right and vice versa.

Identifying elements of public law and private law regulating the environmental law and determining their characteristics, should proceed from the fact that the main criterion for separation of private and public law, is the difference in techniques and methods of influence on environmental relations. To correct their differentiation is also necessary to consider the sequence of factors that affect the formation of the environmental law, according to which the interests of the subjects of environmental relations define the content and the specific properties of these relationships, in turn, determine the nature of legislative requirements.

Environmental legislation is not a mechanical combination rules breaking equality and norms based on relations of power and subordination, actually environmental legislation is built on a combination of such methods.

This relationship is present in some of the legal norms, increasing the level of legal institutions and becomes a fundamental level of environmental law in general. Try to break this relationship means to eliminate environmental law as a branch. Complex (private law and public law) the nature of legalization of environmental relations finds its manifestation terminology in the current legislation. Based on the basic directions of state environmental policy and based on the adoption of specific and interrelated environmental law, formed a set of legal mechanisms impact on certain types of environmental relations. The rules of 
legal mechanisms have both public law and private law and are primarily aimed at ensuring a balance private and public interests in the community.

The value of environmental laws as an independent field lies in the possibility of its use as a tool of the complex legal impact on environmental relations in the state.

The widespread use of public-legal means of regulating environmental relations can not be seen as government interference in private law relations. This fact underlines the need to combine these tools, without which it can not effectively use the environmental legislation. Value the use of private and public law principles in the regulation of environmental relations is not permanent. It depends on the specific conditions of the economy.

Interaction and mutual influence of public law and private law principles specific to regulation of environmental relations. One can not ignore that the dramatic changes of private law regulating environmental relations can not affect the state of public regulation and vice versa. Therefore, changes in the field of private regulation must be accompanied by an analysis of the consequences of such changes in public environmental relations. The same can be said about the changes in the regulation of public environmental management.

The main task of law-making can be formulated as creating, updating and improvement of environmental legislation. Activation of lawmaking that observed in recent years, along with its positive moments, bare and negative consequences. Logical contradictions, gaps and overlaps, lack of mechanisms for the implementation of the environmental law have become common place in lawmaking practice in Ukraine. Basic flaws in lawmaking are causing problems with the implementation of regulations, thereby complicating law enforcement practices.

Today there is a clear need to improve law-making practices, improving the quality of legislation being developed. The need for developing a concept of environmental legislation of Ukraine due primarily needs to improve it, the task of strengthening the rule of law, increasing the need for proper, efficient use of environmental law, need a balance between the stability of environmental laws and the dynamics of public environmental law.

The most common shortcomings of environmental legislation is discrepancy public environmental issues, interests and needs of people, conflicts between legal norms, low level of systematization, lack of sharpness and clarity of the laws, which leads to a violation of law.

Major issues that need solutions are:

1) inadequate legal and organizational support for the acquisition and termination of environmental rights;

2) the settlement of all complex property relations;

3) inadequate measures legal protection of natural objects; 
4) an effective system of environmental management, improvement of the legal framework for environmental management and environmental monitoring;

5) inadequate implementation mechanism and protection of citizens' environmental rights;

6) facilitation of voluntary abandonment of ownership;

7) preventing and overcoming various strains of market pricing mechanism and price parameters of natural resources;

8) legal registration of land and mortgage lending.

The purpose of environmental law is to improve Ukraine on the following basic principles:

- legislative strengthening the legal regime of natural resources;

- balance of the state, public and private interests;

- transparency of state and local government;

- harmonization of domestic environmental legislation with international and European law.

Systematic environmental legislation is the most important factor in organizing legislative activity to achieve the challenges facing the state and society in the field of environmental relations. It provides a uniform understanding and application of the law throughout the state, the treatment requirements of environmental legislation to any and all subjects of environmental relations.

To ensure consistency of environmental legislation is necessary to satisfy a number of conditions:

- the scientific validity of acts of environmental laws;

- a high level of legal awareness and legal culture of society;

- the creation of science-based system of monitoring the effectiveness of environmental laws;

- a priority of international and European law in the national legal system.

Modern environmental law acts are characterized by significant shortcomings, which are the norms that are not governing the specific environmental legislation, but have a declarative character, full of contradictions, unclear wording, stylistic shortcomings and other inaccuracies. Large-scale land and agrarian reforms do not reach their goals through the individual and disparate changes in the environmental legislation. The process of the development of the environmental legislation of Ukraine in recent years has led to the emergence of many non-traditional problems in legal technology. Legal technology category stands out for its complexity, versatility and multidimensional nature. It is characterized by a number of key features, which include the following:

- legal machinery, which is a set of tools and techniques intangible, technical, legal technique shown in the rules (norms) by which she used; 
- legal machinery materializes at legal (normative) acts.

Once the tools and techniques of legal technology really embodied in acts, they become the property of the legislation. The culture of the lawmaking directly provides a coherent statement of the content of the law.

Violation of the law of logic, the inaccuracy of its concepts and formulations used terms uncertainty lead to changes and additions, many requests of different interpretations and explanations, distorting the law and its application. Rules of the legal technique is quite complex in its normative nature and are set by the state requirements about tools and techniques of legal technique for the most perfect preparation and organization of the state laws. To the substantive and formal legal rules legal technology include rules for choosing the proper form of the legal act to regulate certain land relations, preparation of the bill concept, defining the boundaries of the law, the rules of the legal definitions formulation, which create a regulatory framework of the draft.

Among the most important legislative issues at the present stage are:

1) lack of constitutional control at the lawmaking stage;

2) errors forming a text of a statute - transferring of the developed legislative decision to the legal structures and formulas;

3) the power of the organization and expert support of the legislative process;

4) the absence of complete, accurate and practical model of the quality law (norm of law);

5) the absence of logic and consistency in changing of the legislation;

6) design errors in the drafting of the legislative solutions and more.

In this regard, the laws are overwhelmed by the blanket rules, which contain obscure items, adopt many norm legislative acts that contradict the Constitution of Ukraine. The legal technology of the environmental law system of Ukraine is scientifically sound and contains practically proven tools, techniques, methods used in the process of the environmental legislation adaption.

The legal technology of the environmental laws is a special legal phenomenon, which should not only be limited to the practical activity of designing draft acts of the environmental legislation.

Based on theoretical and legal analysis the following types of modern legal techniques of environmental law are identified:

- rule-making - a set of rules, methods, tools and techniques used by the subjects of the legislative process when creating norm legislative acts;

- enforcement - the technique of the formulation and adaption of the preventive acts by the correspondent organizations;

- interpretational - the technique of the formulation of the act, which explains the norm of the law and identifies the precise definition of it; 
- systematization - the technique of the organizing of the norm legislative acts in the organized system.

The important role in the improving of the legal technique plays the Legislative examination. In Ukraine Legislative examination is performed by the Chief Scientific Expert Department of the Verkhovna Rada. Its main task is to conduct a scientific examination of bills conceptual levels; the legal, economic, social appropriateness of the adaption of the law; and its conformity with the Constitution and international treaties, its correspondence to the current level of scientific knowledge, principles of the state policy; forecasting the consequences of their adaption. The problem of the environmental laws is that the drafting of the laws, identification of the future trends of the development of the environmental legislation and participatation of the specialists in their resolution is sporadic.

\section{CONCLUSIONS}

The level of the environmental legislation perfection depends on the legislative technique, the efficiency of its action, deep understanding and appropriate application, and also on the systematization of the environmental legislation. The maximum use of the implementation tools of the legal technique in the preparation of the draft laws is a necessary consequence of the environmental lawmaking. Failure to comply with the requirements of the legal technique in the text of the environmental laws acts leads to such legal errors as adaption of the norms that contradict the Constitution of Ukraine, a reference to the nonexistent norms, incomplete consolidation of circumstances that are essential to the meaning and application of the specific norms of the environmental laws.

The presence of these errors significantly reduces the quality of the acts of environmental legislation, causing difficulties in their interpretation and implementation of the norms of the environmental laws in specific public environmental relations.

\section{SUMMARY}

The problems of the effectiveness of legal regulation of environmental relations have been analyzed in the paper: gaps, collisions, declarative character, contradictions, unclear wording, stylistic shortcomings and other inaccuracies. Prospects for improvement of environmental legislation have been outlined. The main causes of gaps in environmental legislation have been identified. Mechanism to overcome gaps in environmental law is investigated. The author is convinced that one of the main reasons for the low efficiency of the regulatory capacity of environmental law is the existence of collisions. The basic rules to resolve collisions in the legal regulation of 
environmental relations been formulated. The paper emphasizes on interaction of private and public elements of environmental legislation.

\section{REFERENCES}

1. Алексеев С.С. Общая теория права: в 2-х т. М. : Юрид. лит., 1981. T. 1. C. 93.

2. Майстренко О.В. Теоретико-правові аспекти колізій у законодавстві України: автореф. дис. на здобуття наук. ступеня канд. юрид. наук: спец. 12.00.01; Нац. ун-т внутр. справ. Х., 2008. С. 9.

3. Мірошниченко А.М. Колізії в правовому регулюванні земельних відносин в Україні: монографія; Ін-т законодавства Верховної Ради України. К.: Правова єдність, 2009. С. 62.

4. Сидор В.Д. Земельне законодавство України: сучасний стан та перспективи розвитку: монографія. К.: Вид-во “Юридична думка”, 2011. C. 138.

5. Костицький В. Міжнародно-правовий етичний імператив як основа теоретико-методологічного забезпечення розвитку екологічного права. Право Украӥни. 2011. № 2. С. 30.

6. Конституція України, прийнята на п'ятій сесії Верховної Ради України 28 червня 1996 року. URL: https://zakon.rada.gov.ua/laws/show/

\section{Information about the author:} Sydor V. D.,

Doctor of Law, Professor at the Department of Constitutional, Administrative and International Law, Kyiv Institute of Intellectual Property and Law, National University "Odesa Law Academy" 210, Kharkivske highway, Kyiv, 02121, Ukraine 